\title{
QUALITY OF EDUCATIONAL PROGRAMS' AND EVALUATION
}

\section{Milan KLEMENT}

Abstract: The paper treats the posibility of an educational programs quality evaluation based upon a created educational programs evaluation system. To make the use of the evaluation system thus created easier, new software applications were developed.

Key words: educational program, evaluation system, evaluation areas, evaluation criteria.

\section{KVALITA VÝUKOVÝCH PROGRAMŮ A JEJÍ HODNOCENÍ}

Resumé: Př́spěvek se zabývá možností hodnocení kvality výukových programů na základě vytvořeného systému hodnocení výukových programi̊. Z důvodu snadného použití vytvořeného systému hodnocení byly vyvinuty softwarové aplikace, které celý proces evaluace usnadňují.

Klíčová slova: výukový program, systém hodnocení, oblasti hodnocení, hodnotící kritéria.

\section{1 Úvod}

Systém hodnocení výukových programů byl od počátku koncipován tak, aby zahrnoval co nejširší soubor sledovaných vlastností nezbytných pro efektivní a cílené využití potenciálu počítačem řízené a podporované výuky v podmínkách základních škol. S ohledem na tento fakt předpokládá jeho smysluplné použití alespoň základní znalosti a dovednosti při obsluze výpočetní techniky, s přesahem do teorie programovaného učení.

S ohledem na výše uvedené skutečnosti jsou vymezeny základní oblasti a obsahy vzdělávání učitelů prripravovaných $\mathrm{v}$ rámci studia pro výuku na základních školách, jejichž osvojení je nutné pro účinné využití systému hodnocení výukových programů (1, str. 317). Je popsán postup vytváření potřebných kompetencí učitelů vzhledem k použití výpočetní techniky v edukačním procesu a způsob, jak může daná skupina učitelů použít systém hodnocení výukových programů $(2$, str. 99$)$.

Zaměřovali jsme se tedy na dvě skupiny učitelů. První skupinu tvoří učitelé - uživatelé, kteří využívají možností výpočetní techniky pro podporu výuky na základních školách. Proto je jejich vzdělávání zaměřeno především na tři hlavní oblasti. První oblastí je obsluha základních softwarových produktů a obsluha počítače, prričemž je důraz kladen především na praktické dovednosti a znalosti. Druhou oblastí je využití softwarových produktů pro vytváření pedagogických, didaktických a výukových materiálů. Třetí oblast je potom zaměřena na použití výpočetní techniky ve výuce. Zde jsou předávány znalosti a dovednosti z oblasti použití výukových programů, počítačových periferií i počítačových sítí, pro potřeby výuky na základních školách.

Druhou skupinu tvoří učitelé - „odborníci“ v podmínkách školy (dále budeme tuto skupinu označovat pouze jako učitelé - odborníky), schopní počítač nejen obsluhovat, ale také spravovat. Správa se potom může týkat jednotlivých počítačů (instalace programů, konfigurace hardware, instalace a obsluha periferií), dále počítačových učeben (správa centrálních prostředků pro provoz pomocí serveru, definice práv jednotlivých uživatelů, obsluha periferií pro centrální a frontální použití), ale také počítačových sítí a jejich prostředků (obsluha sít’ových serverů, konfigurace počítačů pro připojení do sítě, správa sítové politiky) (3). Součástí potřebných kompetencí je i schopnost upravovat či vytvářet počítačové programy pomocí programovacích jazyků a obsluha softwarových systémů, které umožňují vytváření vyspělých multimediálních, grafických a webových projektů.

\section{Použití systému hodnocení učiteli - uživateli}

Pro potřeby vyhodnocování vlastností výukových programů systémem hodnocení výukových programů byla vyvinuta autorem stati v roce 2004 softwarová aplikace, která celý proces evaluace značně usnadňuje. Aplikace obsahuje celkem 14 hodnotících kritérií v 7 oblastech, v souladu s výsledky ověřování systému hodnocení (4, str. 302). Nejvýznamnějších 7 kritérií je označeno jako 
základní - to jsou ta, které učitelé považují za nezbytné pro posuzování výukových programů. Dalších 7 kritérií je označeno jako doplňková, ta učitelé považují za důležitá, ale netrvají na jejich použití. Nicméně i tato kritéria mohou učitelům pomoci vybrat vhodný výukový program, který by nejlépe vyhovoval jejich potřebám a zároveň splňovat základní předpoklady, které byly vymezeny na základě realizovaného výzkumného šetření.

Aplikace umožňuje také archivaci jednotlivých posuzovaných programů a proto je možné jednotlivé výukové programy vzájemně porovnávat. Níže uvedený obrázek 1 prezentuje uživatelské rozhraní zmíněné aplikace pro hodnocení výukových programů. Učitelé tedy mohou posuzovat výukové programy v 7 hodnotících oblastech O1 - O7. Každá hodnotící oblast potom obsahuje jednotlivá hodnotící kritéria včetně podrobného popisu sledovaných vlastností a jejich interpretace. Podrobný popis př́íslušné hodnotící oblasti a sledovaných vlastností je umístěn v pravé části uživatelského rozhraní.

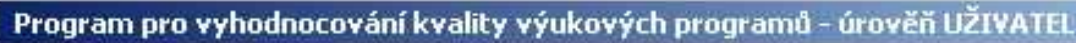

Program Výukové programy Qprogramu

\section{Evaluace vúuleovigch programi podle hodnotici šleály}

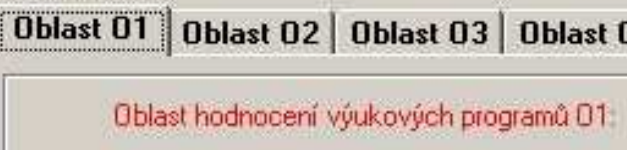 \\ TECHNICKA ZPUSOBILOST VÝUKOVËHO PROGRAMU \\ Splněno základni kritérium \\ Zpưsob ovládáni výukového programu uživatelem.
C ano \\ C ne}

Splnèno doplňkikové kritérium

Možnost modifikace obsahu výukového programu učitelem včetné on-line aktualizace obsahu výukového programu

(6 ano

C ne
Specifikace oblasti Ol a upřesněni významu hodnotícich kritérii

\section{Oblast hodnoceni O1}

Kritéria v této oblasti jsou zaměrena na posuzováni výukového programu $\mathrm{z}$ hlediska technického provedeni. Technické provedení a systémové možnosti výukového programu výrazně ovlivnuji možnost jeho snadné implementace do výuky. Setkáme se zde s kritétii zamĕrenými na príslušenství víukového programu, ale také s kritérii zaměrenými na možnosti instalace či aktualizace obsahu výukového programu.

\section{Význam kritérii}

Základní kritérium ,Zpưsob ovládání výukového programu ux̌ivatelem"

specifikuje zpưsob ovládáni, tedy zda je intuitivni a jednoduché, či složité a neprehledné. Mira prehlednosti a

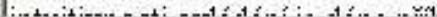

Obr. 1: Aplikace pro evaluaci výukových programů učiteli

Učitelé potom kliknutím na možnost ANO kritérium je splněno, nebo na možnost NE kritérium není splněno, mohou posuzovat vlastnosti hodnoceného programu. Po vyplnění všech položek na záložkách Oblast 1 až Oblast 7, dojde k celkovému vyhodnocení sledovaných vlastností evaluovaného výukového programu. Pokud učitel některé kritérium nepochopí, nemusí danou položku vyplňovat. Vyhodnocení vlastností je patrné z obrázku 2. Hodnotící škála, podle které je možné výukové programy posuzovat, nevyžaduje úplnou prítomnost všech sledovaných vlastností, nebot' se domníváme, že již existující programy je z ohledem na autorský zákon velmi nesnadné upravovat. Proto je tato hodnotící škála spíše zaměřena na vymezení slabých míst výukových programů. 
Program Výukové programy oprogramu

\section{Evaluace vúuleovúch programů podle hodnotici čleály}

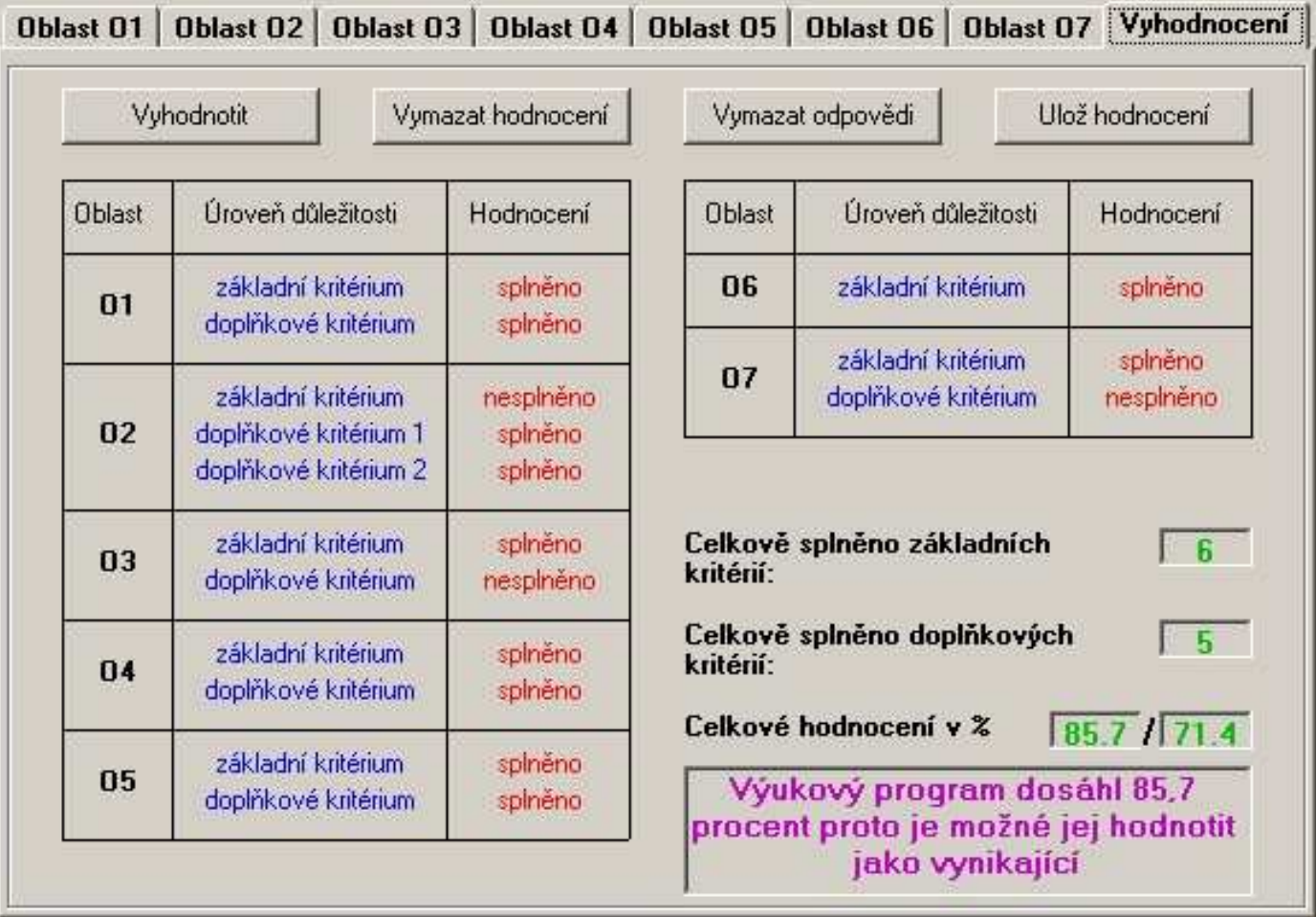

Obr. 2: Aplikace pro evaluaci výukových programů učiteli - vyhodnocení programu

Slabá místa programu je potom možné kompenzovat cíleným působením učitele, či změnou způsobu použití výukového programu. Hodnotící škála má celkem tři stupně:

- Nevyhovující výukový program je ten, který splňuje méně než $60 \%$ základních kritérií a méně než $15 \%$ doplňkových kritérií.

- Vyhovující výukový program je ten, který splňuje více než $60 \%$ ale méně než $80 \%$ základních kritérií. Rozmezí doplňkových kritérií bylo stanovaného od 15\% do $60 \%$. Takovýto výukový program je možné při výuce na základních školách použít, ale některé jeho vlastnosti je nutné korigovat cíleným působením vyučujícího. Tyto programy jsou také vhodnými kandidáty pro úpravu jejich struktury či obsahu pomocí programovacích jazyků, pokud to ovšem dovoluje autorský zákon.

- Vynikající výukový program je ten, který splňuje více než $80 \%$ základních kritériî a více něž $60 \%$ doplňkových kritérií. Takovéto výukové programy je možné využívat při výuce na základních školách bez nutnosti jejich dalších úprav.

3 Použití systému hodnocení učiteli - odborníky

Použití systému hodnocení výukových programů učiteli - odborníky je možné ve dvou rovinách. První rovinou je hodnocení výukových programů, které učitel zakoupí. To znamená, že může použít výše uvedenou softwarovou aplikaci, a vyhodnotit vlastnosti výukového programu v souladu s popsaným postupem v části 2.

Druhou rovinou je využití systému hodnocení výukových programů při úpravě či vytváření výukových aplikací učitelem, nebo odborníkem z komerční sféry. Použití systému hodnocení je zde odlišné, tvůrci výukových programů požadované vlastnosti zapracovávají do programu již při jejich návrhu. Tímto postupem tedy mohou vytvářet výukové programy, které mají všechny požadované vlastnosti, které vymezují jednotlivá kritéria hodnotícího systému. 
Pro potřeby vyhodnocování vlastností při vytváření nebo úpravě výukových programů, podle vytvořeného systému hodnocení byla opět vytvořena softwarová aplikace, která celý proces evaluace značně usnadňuje. Uvedená aplikace umožňuje uživatelům průběžné také sledování a úpravu kvality vytvářeného výukového programu.

Aplikace byla vyvinuta autorem stati práce v roce 2004. Obsahuje celkem 25 hodnotících kritérií v 7 oblastech v souladu s výsledky ověřování systému hodnocení. Nejvýznamnějších 7 kritérií je označeno jako základní - to jsou ta, která učitelé považují za nezbytné pro posuzování výukových programů. Obsah těchto kritérií je nutné zapracovat do vytvářených či upravovaných výukových aplikací.

Dalších 7 kritérií je označeno jako doplňková - to jsou ta, která učitelé považují za důležitá, ale netrvají na jejich použití. Tato kritéria mohou pomoci rozšírit pole působnosti systému hodnocení, který tak může prrispět k vytváření výukových programů zahrnujících všechny podstatné vlastnosti. Dále je v aplikaci obsaženo 11 kritérií označených jako pomocná. Jimi nejsou výukové programy ,automaticky“ hodnoceny a záleží pouze na úvaze tvůrce programu, zda je uplatní. I tato kritéria mohou učitelům pomoci vytvořit vhodný výukový program, který by nejlépe vyhovoval jejich potřebám a zároveň splňovat základní předpoklady vymezené na základě realizovaného výzkumného šetření. Aplikace umožňuje archivaci jednotlivých posuzovaných programů a proto je možné jednotlivé výukové programy vzájemně porovnávat. Níže uvedený obrázek 3 prezentuje uživatelské rozhraní zmíněné aplikace pro hodnocení upravovaných či vytvářených výukových programů.

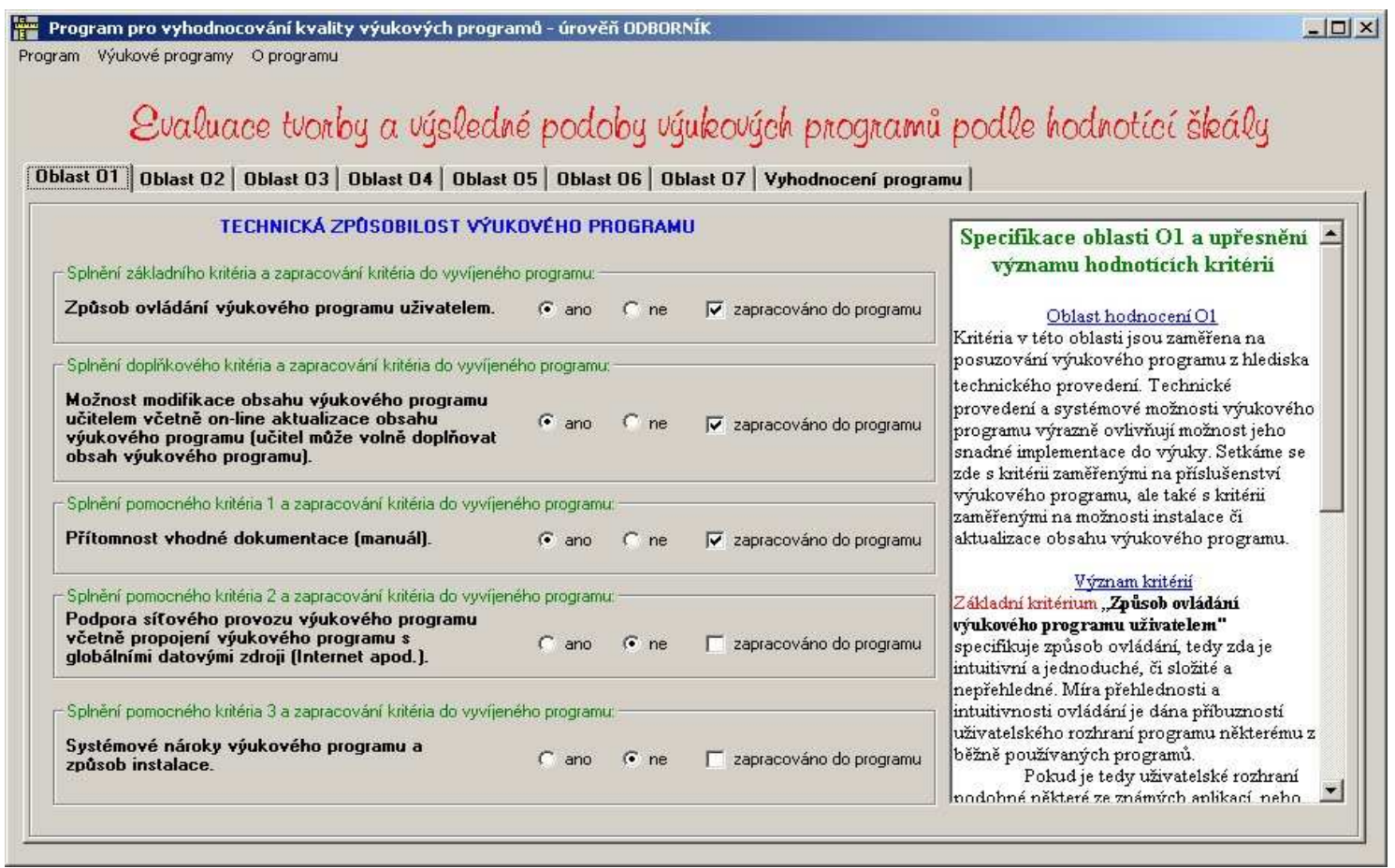

Obr. 3: Aplikace pro evaluaci úpravy či vytváření výukových programů učiteli

Jak je patrné z obrázku 3, každé kritérium obsahuje i položku „zapracováno do programu“. Jeho úkolem je sledování průběhu vytváření či úpravy výukového programu, nebot' uživatel má možnost sledovat, která vlastnost výukového programu vymezená př́slušným hodnotícím kritériem již byla do programu zapracována a která nikoliv. Uživatel programu tedy označí kritéria, která zapracoval do výukového projektu, zaškrtnutím ovládacího prvku CheckBox. Tento postup usnadňuje prrehled o tom, které sledované vlastnosti výukového programu je nutné zapracovat či doplnit. 


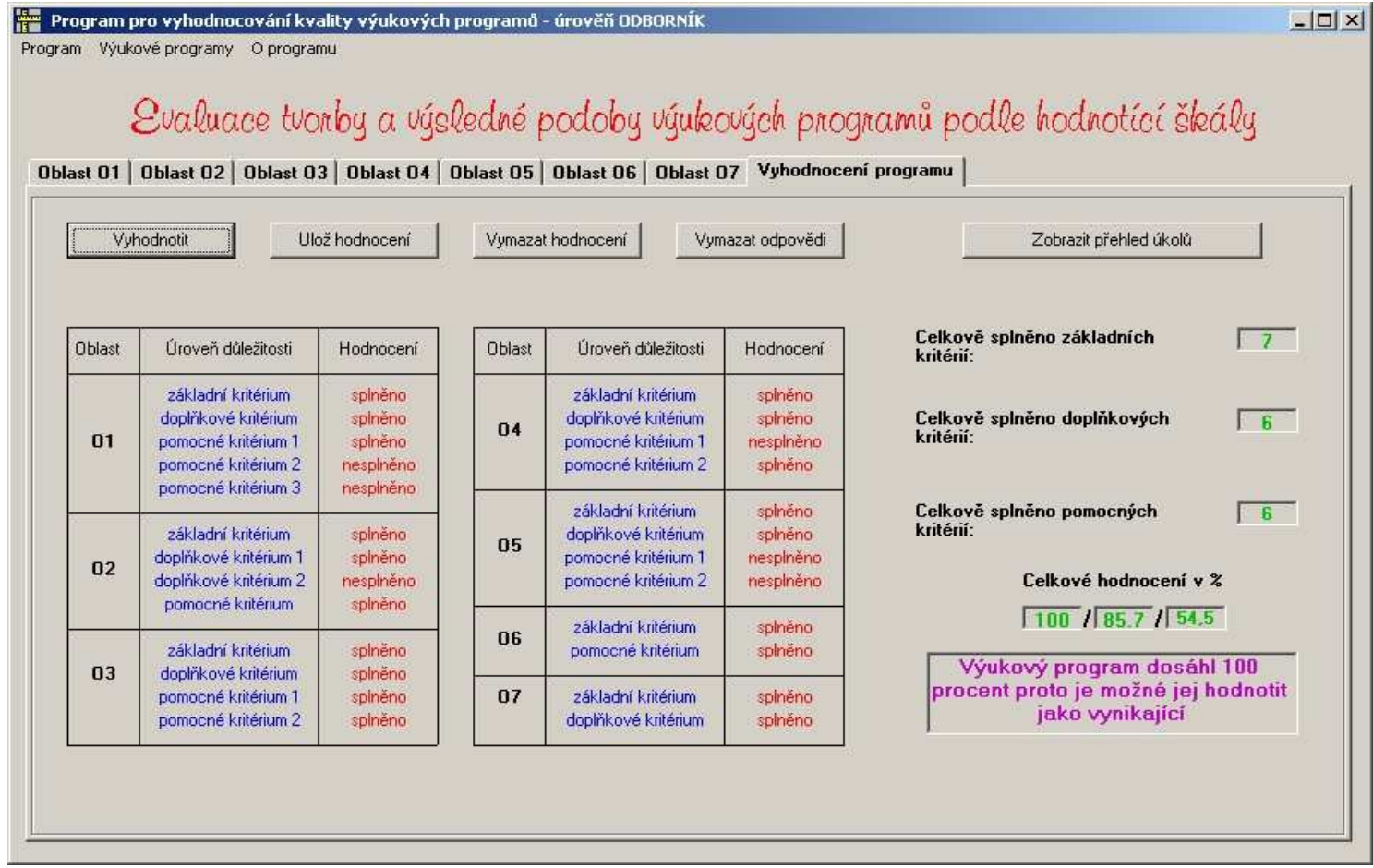

Obr. 4: Aplikace pro evaluaci tvorby výukových programů - vyhodnocení programu

Obrázek 4 ukazuje, jak jsou vyhodnocovány jednotlivé údaje, které učitel vyplní na záložkách hodnotících oblastí O1 až O7. Zobrazovány jsou údaje o splnění jednotlivých kritérií i celkové shrnutí všech údajů.

V souvislosti s vyhodnocením kvality vytvářených či upravovaných výukových programů bylo opět nutné stanovit hodnotící škálu pro posuzování výukových programů. Tato hodnotící škála je „přísnější“ než u verze programu určené k posuzování již vytvořených výukových programů. Pokud je totiž aplikace vytvářena za spoluúčasti učitele, měla by zahrnovat všechny potřebné vlastnosti, nezbytné pro adekvátní využití ve výuce. Tak vznikne výukový program bez „slabých míst“, která by učitel musel kompenzovat vlastním působením či změnou způsobu použití programu. Hodnotící škála má tedy celkem tři stupně:

- Nevyhovující výukový program je ten, který splňuje méně než $70 \%$ základních kritériî a méně než $20 \%$ doplňkových kritérií.

- Vyhovující výukový program splňuje více než $70 \%$, ale méně než $90 \%$ základních kritérií. Rozmezí doplňkových kritérií bylo stanovaného od $20 \%$ do $40 \%$. Takovýto výukový program je možné při výuce na základních školách použít, ale některé jeho vlastnosti je nutné korigovat cíleným působením vyučujícího. Tyto programy jsou také vhodnými kandidáty pro další úpravu jejich struktury či obsahu pomocí programovacích jazyků.

- Vynikající výukový program je ten, který splňuje více než $90 \%$ základních kritérií a více něž $40 \%$ doplňkových kritérií. Takovéto výukové programy je možné využívat při výuce na základních školách bez nutnosti jejich dalších úprav.

Další částí programu je vyhodnocení stavu zapracování jednotlivých sledovaných znaků do výukového programu. Jak již bylo uvedeno tvůrce výukového programu může zapracovaná kritéria označovat na záložkách $\mathrm{O} 1$ až O7. Použitím tlačítka „Zobrazit přehled úkolů“ dojde k zobrazení doplňkového modulu programu, ve kterém je zobrazen souhrn kritérií a stav jejich zapracování. Doplňkový modul je uveden na dalším obrázku 5.

Uvedený modul obsahuje dvě další záložky sloužící k zobrazení kritérií, která je nutné do programu zapracovat - jsou to základní kritéria. Dále pak seznam kritérií, která mohou být do programu zapracována - jsou to doplňková kritéria.

\section{Závěr}

Pomocí uvedených programů a hodnotících škál je tedy možné velmi rychle a snadno posuzovat stav vytváření či úpravy výukových programů. 


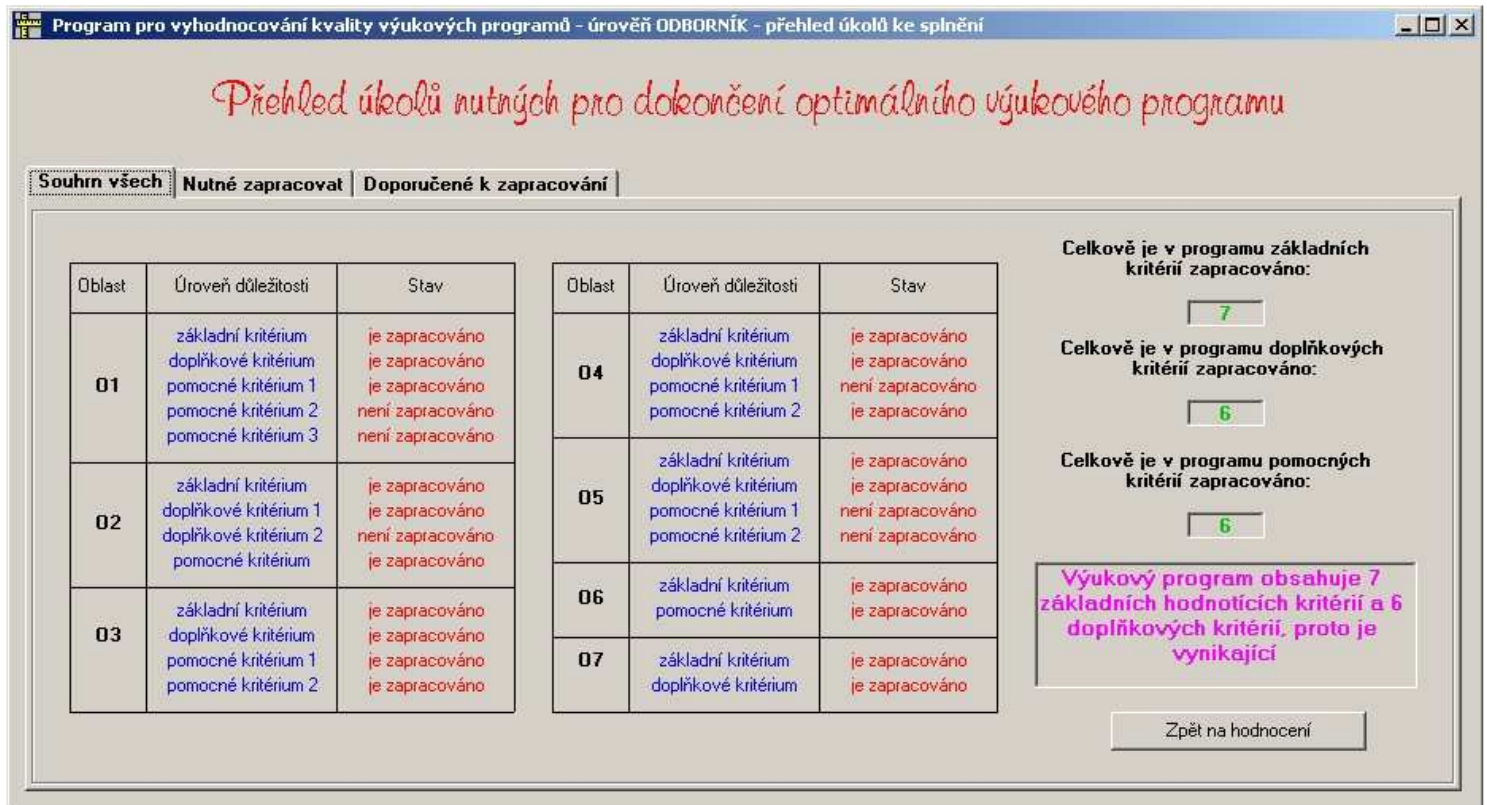

Obr. 5: Doplňkový modul-přehled úkolů

Uvedené aplikace byly volně distribuovány mezi nejširší odbornou veřejnost a to pomocí webového portálu, který má adresu http://kteiv.upol.cz a byl zřízen autorem předložené stati. Použití výukových programů je tedy všestranné a je omezeno pouze množstvím a typem výukových aplikací dodávaných firmami zabývajícími se touto činností. Takovýto software ale ne vždy vyhovuje požadavkům vyučujícího nebo pro některé oblasti výuky není vytvořen. Proto jsme do uvedené metodiky zapracovali problematiku hodnocení výukového software.

Toto zapracování vychází z následujícího předpokladu. Pokud jsme schopni posoudit výukový program, víme také, jak má být uspořádán a co má obsahovat. Proto můžeme již při vlastním návrhu použít výše uvedená kritéria a tak docílit vhodnosti vytvářeného výukového programu s ohledem na edukační proces a zásady programovaného vyučování.

Proto považujeme jako vhodné budoucí učitele technických předmětů $v$ rámci pregraduální přípravy naučit potřebným znalostem a dovednostem, které jim umožní tvorbu vlastních výukových aplikací. Pokud si učitel technických předmětů osvojí tyto poznatky, bude schopen využít objektově orientované jazyky ktvorbě výukového software, který bude respektovat jeho pojetí výuky a dovolí mu velmi flexibilně reagovat na požadavky edukačního procesu.

\section{Literatura}

(1) KLEMENT, M. Pojetí výuky ICT na Katedře technické a informační výchovy $\mathrm{PdF}$ UP. In DIDMATTECH 2003 (sborník). Pedagogická fakulta UP v Olomouci, 4. a 5. července 2003. Olomouc: UP, 2003, s. 315 320. ISBN 80-7067-664-7.

(2) KLEMENT, M. - ZABLOUDILOVÁ, A. Pojetí a uspořádání výuky ICT v rámci Pedagogické fakulty UP Olomouc. In Sborník $z$ mezinárodní vědecké konference eLearning ve vysokoškolském vzdělávání, Zlín 4 a 5. června 2003. Zlín: UTB, 2003, s. 97 - 104. ISBN 807318-138-X.

(3) KLEMENT, M. Výpočetní technika software a hardware. 1. vyd. Olomouc: UP, 2002. 178 s. ISBN 80-244-4012-6.

(4) KLEMENT, M. Kritéria hodnocení výukového software. In DIDMATTECH 2003 (sborník). Pedagogická fakulta UP v Olomouci, 4. a 5. července 2003. Olomouc: UP, 2003, s. 301 - 304. ISBN 80-7067-664-7.
PhDr. Milan Klement, Ph.D.,
Katedra technické a informační výchovy,
Pedagogická fakulta UP, Žižkovo nám. č. 5, 771 40, Olomouc, ČR, tel: 058/ 5635811, e-mail: milan.klement@upol.cz www pracovišstě: www.kteiv.upol.cz 